\title{
Amar Munkar Nahi Ma'ruf: Studi Lirik Lagu Dangdut Koplo Jaran Goyang dan Parodinya
}

Farhan $^{\mathrm{a}, 1, *}$

${ }^{a}$ Program Studi Komunikasi Penyiaran Islam, Fakultas Agama Islam Universitas Nurul Jadid,67291, Indonesia

Ifarhan.alim11@gmail.com

Riwayat Artikel:

Diterima: Juni 2019

Direvisi : Juli 2019

Disetujui:Agustus 2019

Kata Kunci:

Amar Ma'ruf Nahi Munkar

Dandut Koplo

Media Dakwah

Keywords:

Amar Ma'ruf Nahi Munkar

Crazy Dandut

Media of Dakwah

\begin{abstract}
Abstrak:
Tulisan ini mengkaji dinamika perkembangan musik dangdut koplo di Nusantara dalam perspektif dakwah dan komunikasi. Perkembangan Produksi music dangdut (koplo) semakin mendapatkan tempat dikalangan masyarakat kekinian. Didukung dengan Industri media musik yang semakin meningkat setiap tahun seiring perkembangan konvergensi media konvensional terkoneksi dengan new media (internet). Penciptaan lirik lagu dangdut koplo berjudul 'jaran Goyang' dan parodinya memiliki pengaruh cukup kuat dalam mengubah paradigma pendengar/penonton. Efek lirik lagu dangdut koplo 'jaran goyang' tidak hanya merubah pola berpikir dan berperilaku. Melalui paradigma Amar Ma'ruf Nahi Mungkar dan kajian media dengan pendekatan etnografi virtual di media sosial You tube, penelitian menyimpulkan bahwa lirik lagu dangdut koplo berjudul 'jaran goyang' mengandung pesan perilaku tidak terpuji (Amar 'Munkar') dan bertentangan dengan dokrin agama Islam. Sedangkan parodi lirik lagu 'Jaran Goyang' menunjukkan pesan-pesan kebenaran dan kebajikan selaras dengan ajaran Islam (Amar Ma'ruf), sekaligus merupakan praktik metode dakwah kekikian kepada objek dakwah dari komunitas pecinta musik. Tantangan pendakwah masa depan diperlukan kontinuitas massif dalam mensinergikan pesan-pesan dakwah dengan dinamisasi seni musik dangdut.
\end{abstract}

\begin{abstract}
:
This paper examines the dynamics of the development of music dangdut koplo in Indonesia through perspective of da'wah and communication. The progress of production dangdut music (koplo) is increasingly gaining around today's society. Supported by the music media industry which is every year increasingly as the development of conventional media convergence is connected to the new media (internet). The creation of the lyrics of the song dangdut koplo entitled 'jaran Goyang' and its parody has quite a powerful influence in changing the listener / audience paradigm. The effect of the lyrics of the song dangdut koplo 'jaran goyang' not only changes the pattern of thinking and behaving. Through the Amar Ma'ruf Nahi Mungkar paradigm and media studies using a virtual ethnographic approach on social media You Tube, the study concluded that the lyrics of the song dangdut koplo titled 'jaran goyang' contain messages of dishonorable behavior (Amar 'Munkar') and are contrary to Islamic religious doctrine. Whereas the parody of the song 'Jaran Goyang' shows the messages of truth and virtue in harmony with the teachings of Islam (Amar Ma'ruf), as well as the practice of the method of preaching to the object of preaching from the music lovers community. The challenge of future preachers requires massive continuity in synergizing the messages of da'wah with the dynamics art of the dangdut music
\end{abstract}




\section{Pendahuluan}

Proses dialog Islam dengan tradisi masyarakat diwujudkan dalam mekanisme proses kultural dalam menghadapi negosiasi lokal. Perpaduan antara Islam dengan tradisi masyarakat ini adalah sebuah kekayaan tafsir lokal agar Islam tidak tampil hampa terhadap realitas yang sesungguhnya. Islam tidak harus dipersepsikan sebagai Islam yang ada di Arab, tetapi Islam mesti berdialog dengan tradisi lokal masyarakat setempat. ${ }^{1}$ akulturasi antara Islam dan budaya Jawa terjadi dalam banyak hal, misalnya, arsitektur, seni ukir, kesenian wayang, pola pemakaman, dan seni sastra (seperti babad, hikayat, dan lainnya). ${ }^{2}$

Seni musik sejak masa penyebaran Islam telah dilakukan para wali (wali sanga) sejak abad ke15 M. Seni musik sebagai media dakwah menandakan pemanfaatan budaya lokal yang relevan dengan kondisi masyarakat (mad'u). Dakwah dan budaya lokal saling mendukung eksistensi masing-masing. Misalnya, model dakwah Sunan Kalijaga, menunjukkan beberapa bentuk akulturasi yang telah diciptakan oleh beliau, keseluruhannya memiliki nilai Islam yang kental. Budaya lokal mendukung keberlangsungan dan keberhasilan dakwah serta bermanfaat bagi kelestarian budaya itu sendiri. ${ }^{3}$ Salah satu hasi ciptaan Sunan Kalijaga berjudul 'Lir ilir'. tembang Lir-ilir merupakan tembang yang diciptakan Sunan Kalijaga untuk menyebarkan agama Islam, dan tembang permainan yang digunakan anak-anak ketika bermain. Tembang Lir-ilir juga dapat digunakan dalam pernikahan adat Jawa, dikarenakan tembang Lir-ilir merupakan tembang teladan yang berguna bagi semua kalangan. ${ }^{4}$

Lagu atau tembang ini menceritakan tentang perjuangan kaum muslim untuk bisa menjadi manusia baik seutuhnya. Makna tandure wis sumilir yang artinya sudah saatnya. Tak ijo royoroyo tak sengguh penganten anyar, dapat dikiaskan sebagai lambang agama Islam yang baru masuk ke tanah Jawa dan diibaratkan seperti pengantin baru. Warna hijau juga melambangkan warna yang melambangkan agama Islam. Cah angon penekno blimbing kuwi, lunyu-lunyu penekno kanggo masuh dodotiro, diartikan sebagai ajakan kepada seluruh manusia untuk memanjat dan mengambil buah belimbing. Buah belimbing yang bergerigi sejumlah lima buah diibaratkan sebagai lambang ajaran agama Islam (5 Rukun Islam). Meski susah dan berat manusia harus bisa mencari buah belimbing tersebut untuk "mencuci" hati dan pakaiannya. ${ }^{5}$ Warisan sunan Kalijaga tersebut tetap dipelajari dan berkembang dalam kehidupan masyarakat Jawa hingga sekarang.

Begitu juga yang dilakukan sunan Bonang, Dalam menyebarkan agama Islam, Sunan Bonang selalu menyesuaikan diri dengan corak kebudayaan masyarakat Jawa. Beliau dianggap sebagai pencipta gending (lagu) pertama dalam rangka siar agama Islam. Sunan Bonang dan wali-wali lainnya, menggunakan wayang dan musik gamelan sebagai sarana dakwah Islam. Sunan Bonang sendiri menciptakan lagu-lagu untuk kegiatan dakwah yang dikenal dengan nama Tembang Durma (Macapat). ${ }^{6}$ Sunan Bonang mengakomodasikan Islam sebagai ajaran agama yang mengalami historisasi dengan kebudayaan, misalnya dengan mengubah gamelan Jawa yang saat itu kental dengan estetika Hindu menjadi bernuansa zikir yang mendorong kecintaan pada kehidupan transendental seperti tembang "tombo ati". ${ }^{7}$

Perkembangan musik dangdut semakin mendapatkan tempat yang baik ditengah masyarakat. Terutama genre dangdut koplo di daerah Jawa. Banyak lirik lagu baru yang bermunculan

Zuhdi, Muhammad Harfin. Dakwah dan dialektika akulturasi budaya. Religia, [S.1.], oct. 2017. http://ejournal.iainpekalongan.ac.id/index.php/Religia/article/view/122 Date accessed: 19 feb. 2019.

2 .Donny Khoirul Azis, Akulturasi islam dan budaya jawa. fikrah, Fikrah, Vol. I, No. 2, Juli-Desember 2013, 254

${ }^{3}$ Arifani, M. A. 2010. Model pengembangan dakwah berbasis budaya lokal. Ilmu Dakwah: Academic Journal for Homiletic Studies, 5(15), 849-878.

${ }^{4}$ Afriyanti, N. 2017. Teks Tembang Lir-ilir Pada Pernikahan Adat Jawa (Kajian Semiotik) (Doctoral dissertation, UNIMED).

${ }^{5}$ Ariani, Iva, 2011. Ajaran Tasawuf Sunan Kalijaga dan Pengaruhnya bagi Perkembangan

Pertunjukan Wayang Kulit di Indonesia. Fakultas Filsafat UGM, Yogyakarta

${ }^{6} \mathrm{https} / / / \mathrm{www}$. kompasiana.com/ginanjarinu/5528a6116ea834025e8b45cb/musik-dan-penyebaran-agama-islam

Zuhdi, M. H, 2017. Dakwah dan Dialektika Akulturasi Budaya. RELIGIA. 
disebabkan persaingan industri media musik era milenial. Semakin fenomenal lirik lagu yang disajikan, semakin mendapatkan pendengar dan penonton yang meningkat.

Secara umum musik dangdut dikenal dan diperkenalkan melalui media televisi pada tahun 1970/80-an, ${ }^{8}$ dan terus berkembanga pada tahun 1990-an hingga tahun 2000an. Era reformasi sejak tahun1998 memiliki peran cukup besar dalam perkembangan Industri musik, khususnya dangdut koplo. ${ }^{9}$ Dangdut koplo setidaknya memiliki rating yang terus meningkat dibanding genre dangdut lainnya seperti dangdut original, dangdut rock, dangdut Pop, dangdut jaipongan, dan dangdut House.

Komunitas pecinta musik dangdut koplo bermunculan dengan ciri khas dan karakteristik masing-masing vokal. Naiknya intensitas atensi masyarakat akan dangdut koplo telah menjadi lonjakan besar bagi masyarakat pelakunya. Dangdut koplo seakan menjadi selera bersama, selera lokal yang menasional. ${ }^{10}$ Dangdut koplo pada umumnya berkembang di Jawa Timur, Jawa Barat, dan Jawa Tengah, yang juga mengusung budaya lokal dalam lirik-liriknya.

Di Jawa Timur saja terdapat beberapa grup musik Orkes Melayu (OM) yang telah berkembang dan dikenal luas oleh kalangan masyarakat. Setidaknya ada enam grup yang paling populer dan masik eksis hingga sekarang, yaitu Orkes dangdut Palapa dari Sidoarjo sejak 1998, New Pallapa dari Sidoarjo sejak 2004, Sera di Surabaya sejak 1990-an, Sagita dari Nganjuk sejak 2009 dan Sonata di Jombang sejak 1993.

Masing-masing Orkes Melayu menampilkan lirik lagu dan vokal yang berbeda-beda. Bahkan sebagian lirik lagu yang diciptakan tidak jarang merupakan kolaborasi dan akulturasi bahasabahasa yang menunjukkan multikultural sendiri dalam pertunjukan musik dangdut. Misalnya, penelitian M. Kamaluddin, menyebutkan Keberadaan dangdut koplo di tengah masyarakat yang majemuk merepresentasikan unsur multikultural dengan eksistensi lagu dari beragam bahasa, yakni bahasa Indonesia (Akad), Jawa (Kelangan), Sunda (Mawar Bodas), Inggris (Someone Like You), Latin (Despacito), India (Tum Hi Ho) bahkan Arab (Kun Anta). ${ }^{11}$

Seni musik memang efektif dipergunakan sebagai media untuk menyampaikan kebaikan, baik melalui lirik lagu maupun proses mempertunjukkannya. Sehingga masyarakat pecinta musik, tetap menjaga unsur-unsur kebaikan yang ada dalam pertunjukkan seni musik. Kendatipun, dalam beberapa pertunjukkan dangdut 'terkadang' terjadi peristiwa-peristiwa yang tidak diinginkan. Seperti peristiwa tawuran usai digelarnya konser dangdut di Probolinggo pada 02 November 2018. Even bertema 'Probolinggo Tempo Doeloe', digelar di Alun-Alun Kota Probolinggo. Adu jotos dan aksi lempar batu, yang melibatkan puluhan pemuda di Kota Probolinggo itu, berlangsung sekitar 15 menit. $^{12}$

Penyebutan nama "dangdut" menurut Putu Wijaya dalam Pandu, pada awalnya ada pada majalah Tempo edisi 27 Mei 1972. Bahwa lagu Boneka dari India yang dinyanyikan oleh Titiek Sandhora adalah campuran lagu Melayu, irama padang pasir, dan "dang-ding-dut" India. Sebutan ini selanjutnya diringkas menjadi "dangdut" saja. ${ }^{13}$ Terus mengalami perkembangan hingga berkembang di era modern saat ini. Sedangkan masa orde lama (Soerkarno) semua pengaruh asing semasuk musik sempat dilarang pada tahun 1960-an. Karena itu, perkembangan Orkes

\footnotetext{
${ }^{8}$ Andrew N. Weintraub, 2010, A social and Musical History Indonesia's Most Popular Music (Oxford University.

${ }^{9}$ Raditya, M. H., \& Simatupang, G. L. L., 2018. Negosiasi Kultural dan Musikal Dangdut Koplo pada Orkes Melayu Sonata di Jombang. Panggung, 28(4), 434-435.

${ }^{10}$ Raditya, M. H. 2013. Dangdut Koplo: Selera Lokal Menjadi Selera Nasional. Jurnal Seni Musik, 2.

${ }^{11}$ Kamaluddin, M. 2018. Representasi Multikultural dalam Pertunjukkan Musik Dangdut Koplo. Proceeding of The URECOL, 132-139.

${ }^{12}$ https://news.detik.com/jawatimur/4326740/tawuran-antar-pemuda-terjadi-usai-nonton-konser-dangdut, diakses 18 Februari 2019. Berita terkait tawuran pasca atau saat pertunjukan dangdut terkadang disebabkan persoalan kecil yang dibesar-besarkan oleh geng atau pemuda yang mabuk. Lihat juga tawuran antar penonton orkes New Pallapa Jombang tahun 2018 dalam tayangan media audio visual Youtube https://www.youtube.com/watch?v=bOHh2uvDQNQ

13 Pandu Diptya Yoga, 2013. Hubungan Antara Musik Dangdut Koplo dan Lingkungan gang Doly, Apron: Jurnal Pemikiran Seni Pertunjukan, Unesa, Vol.2 No. 2.
} 
Melayu dimainkan di tingkat lokal saja dalam acara-acara khusus. Baru kemudian tahun 1976 mulai berkembang lagi kepermukaan. ${ }^{14}$

Musik dangdut pada awal perkembangannya juga dipergunakan sebagai media dakwah. Penyanyi terkenal sebagai raja dangdut Roma Irama (L. 11 Desember 1946) telah menciptakan banyak lirik lagu yang relevan dengan budaya masyarakat. Lagu-lagu ciptaan Roma Irama memiliki karakteristik lagu-lagu dengan lirik dakwah.

Pelopor musik dangdut memang merujuk pada Oma Irama, tetapi bukan ia seorang yang menggaungkan Orkes Melayu dalam menciptakan musik dangdut. Aktor-aktor sebelumnya, baik Orkes Melayu dan penyanyi, seperti Ellya Khadam, A. Rafiq, Elvy Sukaesih, dan sebagainya bersama-sama membangun dangdut. Namun, tidak dipungkiri bahwa Oma Irama adalah sosok yang kreatif dalam menciptakan musikalitas yang berbeda melalui grup Soneta yang fenomenal. ${ }^{15}$

Dalam lirik-lirik musik dangdut Rhoma Irama antara tahun 1970-1980 terdapat nilai-nilai moral yang dapat diimplementasikan dalam kehidupan individu, kehidupan keluarga, kehidupan masyarakat, kehidupan berbangsa dan bernegara, serta dalam kehidupan beragama. Fakta-fakta dalam kehidupan manusia di Indonesia banyak terjadi kasus-kasus amoral yang tidak sesuai dengan norma-norma di masyarakat maupun normanorma yang berasal dari hukum (wahyu) Tuhan. Nilai-nilai moral yang terdapat dalam lirik-lirik musik dangdut Rhoma Irama antara lain: nilai amanah, nilai benar (as-Ṣiddīq), nilai kejujuran, nilai keadilan (al-'adl), nilai kasih sayang (al-Rahmmah), nilai persaudaraan, nilai persatuan dan nilai toleransi (tasamuh).

Nilai-nilai moral tersebut relevan untuk diimplementasikan dalam segala zaman, yang meliputi masa lampau, masa kini dan masa yang akan datang. Hal ini disebabkan yang menjadi rujukan utama dalam lirik-lirik musik dangdut tersebut adalah bersumber dari al-Qur"an dan hadis. Nilainilai moral yang terdapat dalam lirik-lirik musik dangdut Rhoma Irama dapat diimplementasikan dalam kehidupan individu, keluarga, kehidupan masyarakat, kehidupan berbangsa dan bernegara dan dalam kehidupan beragama. ${ }^{16}$

Perkembangan dangdut sejak tahun 2014 semakin ramai kemunculan lagu yang dinyanyikan para vokal baru. diantaranya Nella Kharisma yang berada di grup OM Lagista membawakan lagu berjudul 'Jaran Goyang'. Lirik lagu ciptaan Andi Bendol (kelahiran Bantul tahun 1988) telah memikat banyak perhatian, utamanya sejak tahun 2017 sejak diviralkan oleh Lagista. Dalam lirik lagu tersebut terdapat 3 bahasa yang digunakan, yaitu bahasa Indonesia, Jawa, dan Inggris. Pesan yang disampaikan baik tersurat maupun tersirat bisa diresapi dalam tiap baitnya. Meluapkan kekesalan dan kekecewaannya karena pengkhianatan cinta yang telah terpondasi dengan kuat dan kokoh akan tetapi di sisi lain, cintanya telah dibayar dengan dusta sehingga pengarang ingin membalaskan dendamnya dengan ajian jaran goyang dan semar mesem. ${ }^{17}$

Setelah di publish di media youtube, lagu 'Jaran Goyang' sempat viral di media sosial. Bahkan diberitakan pada 27 Desember 2017 lagu tersebut berada dalam 'Top Song ASEAN' yang hita dan viral kala itu, meskipun masih berada dibawah Thailand dan Vietnam. ${ }^{18}$ Bahkan lirik lagu 'Jaran Goyang' ini lalu memunculkan beberapa parodi 'Jaran Goyang' dari vokal-vokal lain dengan lirik berbeda. Inilah yang menjadi ketertarikan peneliti mengkaji secara akademis, dengan

\footnotetext{
${ }^{14}$ Raditya, M. H., \& Simatupang, G. L. L. 2018. Negosiasi Kultural dan Musikal Dangdut Koplo pada Orkes Melayu Sonata di Jombang. Panggung, 28(4), 437.

${ }^{15}$ Ibid, 437.

${ }^{16}$ Mustolehudin, M. 2012. Nilai-nilai Moral dalam Lirik Musik Dangdut Rhoma Irama antara Tahun 1970-1980 (Doctoral dissertation, IAIN Walisongo).

${ }^{17}$ Ardiyanti, D., \& Setyorini, R. 2018. Analisis Campur Kode pada Lirik Lagu Jaran Goyang Dipopulerkan oleh Nella Kharisma. SAP (Susunan Artikel Pendidikan), 2(3). Andi Bendol, pria kelahiran tahun 1988, asal Bantul ini adalah orang yang paling bertanggung jawab atas melambungnya lagu Jaran Goyang. http://jogja.tribunnews.com/2017/12/20/inilah-sosok-wong-bantul-si-pencipta-lagujaran-goyang-yang-sangat-populer-di-youtube-itu.

${ }^{18} \mathrm{http}$ ://suryamalang.tribunnews.com/2017/12/29/inilah-top-song-di-asean-lagu-jaran-goyang-milik-nella-kharisma-berada-di-urutannomor?page $=4$.
} 
judul 'Amar Munkar Nahi Ma'ruf perspektif dakwah era milenial studi lirik lagu Jaran Goyang dan parodinya.

\section{Metode Penelitian}

Istilah penelitian kualitatif adalah jenis penelitian yang temuan-temuannya tidak diperoleh melalui prosedur statistik atau bentuk hitungan lainnya.19 Dari definisi singkat ini bisa menjelaskan penelitian ini merupakan penelitian kualitatif deskriptif dan menggunakan pendekatan etnografi virtual sebagai pisau analisis di dalam memahami isi lagu yang diteliti. Dengan menggunakan jenis penelitian ini, peneliti juga akan lebih leluasa dalam mengembangkan penelitian yakni sebagai gabungankonsep pengorganisasian antara observasi dan teknik wawancara untuk merekam dinamika perilaku masyarakat ${ }^{20}$ sehingga etnografi memiliki kemampuan untuk melakukan eksplorasi dalam hubungan digital ${ }^{21}$

Dalam pendekatan etnografi virtual ditegaskan bahwa verifikasi keaslian data bukanlah topik yang dapat dipisahkan dari etnografi itu sendiri. Dengan kata lain, bahwa kebenaran data dari dunia virtual adalah proses yang situasional yang berlangsung reflexsive dan dinegosiasikan, bukan sebuah proses objectivikasi yang akan dilakukan hanya ketika menganalisis data. Tidak ada gunanya menentukan apakah bahwa keaslian seseorang di dunia virtual harus dapat dilihat langsung orangnya dan hal itu dinilai sebagai sebuah syarat mutlak. Pijakan utama bagi seorang etnografer virtual, janganlah membawa kriteria eksternal untuk menilai apakah aman untuk mempercayai apa yang informan katakan, namun datanglah ke dunia virtual untuk memahami bagaimana informan menilai keaslian informasi yang disampaikannya. ${ }^{22}$

Sedangkan teknik pengumpulan data menggunakan teknik dokumentasi. Seperti yang diungkapkan oleh Suharsini Arikunto, bahwa metode dokumentasi adalah metode mencari data mengenai hal-hal yang variabelnya berupa catatan, transkrip, buku, surat kabar, majalah, prasasti, notulen, rapat, dan lain sebagainya. Berdasarkan penjelasan di atas teknik pengumpulan data yang digunakan dalam penelitian ini adalah memilih YouTube sebagai sumber data. pengumpulan data dilakukan secara berkesinambungan dengan mengkaji dan menganalisis media YouTube khususnya pada lirik lagu jaran goyang dan parodinya.Hasil Penelitian

\section{Hasil dan Pembahasan}

\section{A. Kemungkaran dalam Lirik lagu "Jaran Goyang"}

Lirik lagu jaran goyang yang dinyanyikan Nella kharisma telah dipublikasikan sejak April 2017. Karya ciptaan Andi Mbendol ini cukup memikat hati para pendengar atau penonton. Bahkan sempat menjadi trend semua kalangan baik generasi tua hingga muda, dengan viewer di Youtube mencapai 235 juta untuk video live nya dan 53 Juta penonton untuk official videonya. Penggunaan campuran bahasa Jawa, Inggris dan Indonesia ini bisa jadi merupakan indikasi ketertarikan dan mendapat perhatian cukup besar dari pecinta musik dangdut. ${ }^{23}$

Secara tersirat dan tersurat lirik lagu jaran goyang menunjukkan ajakan atau informasi yang tidak baik dalam ajaran agama Islam. Bahkan lirik nya Bertentangan dengan Konsep Amar Mar'uf nahi mungkar. Namun, keberadaan lirik lagu jaran goyang tetap mendapatkan kesempatan untuk di publikasikan.

Amar Mar'uf adalah konsep mengajak kepada kebaikan kepada sesama manusia bahkan kepada makhluk lain (QS. Ali Imron 104)

\footnotetext{
${ }^{19}$ Anselm Straus \& Juliet Corbin, 2013. Dasar-dasar Penelitian Kualitatif, (Yogyakarta: Pustaka Pelajar, h. 4.

${ }^{20}$ Mariampolski. H. “The Power of Etnography, ” International Journal of Market Research, 41 (1), h. 12

${ }^{21}$ Rulli Nasrullah, 2014, Teori Dan Riset Media Siber, Jakarta: Prenada Media Group, h. 90

${ }^{22}$ Hine, C. 2000. Virtual Ethnography. London: Sage Publications Ltd.

${ }^{23}$ Devi Ardiyanti dan Ririn Setyorini, Analisis campur kode pada lirik lagu jaran goyang dipopulerkan oleh Nella Kharisma, jurnal SAP vol. 2 No. 3 April 2018, 255-261
} 
Begitu pun dalam konsep nahi mungkar dengan segala kerendahan hati sesama manusia saling memotivasi untuk meninggalkan kejelekan atau perbuatan jelek/buruk. Lirik lagu jaran goyang justru mengajak kepada keburukan ('amar Munkar'). teks pada lirik nya sangat jelas menyebutkan hal tersebut. Demikian hal nya dalam kategori nahi ma'ruf.

Pada salah satu lirik misalnya..." Gek Ayo mangkat dukun, rasah kakean ngelamun. Ndukun, ndukun, ndukun ayo dukun ".

Konsep Amar Mar'uf nahi mungkar sebagai esensi dakwah harus dilakukan sepanjang masa. Karena tujuan mulia dakwah tidak lain adalah menyelamatkan hidup manusia di dunia dan akhirat. Sebagaimana pendapat Dermawan dalam zakiyatul menyatakan bahwa dakwah bertujuan mempertemukan kembali fitrah manusia dengan agama atau menyadarkan manusia supaya mengakui kebenaran Islam dan mengamalkan ajaran Islam. ${ }^{24}$

\section{B. Materi Dakwah dalam Parodi}

Parodi lirik lagu 'jaran goyang' yang begitu mudah diterima kalangan umat Islam menginspirasi pendakwah masa kini membuat parodi lirik lagu berisi dakwah. Parodi yang diciptakan Kery Astina merupakan bentuk dakwah melalui musik yang berisi ajakan kepada kebaikan.

Adapun lirik dari lagu Jaran Goyang seperti berikut ini

Apa salah dan dosaku, sayang

Cinta suciku kau buang-buang

Lihat jurus yang kan ku berikan

Jaran goyang, jaran goyang

Sayang, janganlah kau waton serem

Hubungan kita semula adem

Tapi sekarang kecut bagaikan asem

Semar mesem, semar mesem

Jurus yang sangat ampuh, teruji terpercaya tanpa anjuran dokter, tanpa harus muter-muter cukup siji solusinya, pergi ke mbah dukun saja

Langsung sambat, "Mbah, saya putus cinta"

Kalau tidak berhasil, pakai jurus yang kedua

Semar mesem namanya, jaran goyang jodohnya

Cen rodok ndagel syarate, penting di lakoni wae

Ndang di cubo, mesthi kasil terbukti kasiate, genjrot

Dan dudidam aku padamu, I love you

I can't stop loving you oh darling

Jaran goyang menunggumu

Apa salah dan dosaku, sayang, cinta suciku kau buang-buang Lihat jurus yang kan ku berikan, jaran goyang, jaran goyang Sayang, janganlah kau waton serem, hubungan kita semula adem

Tapi sekarang kecut bagaikan asem, semar mesem, semar mesem

Wes cukup stop mandekko disek sek sek

\footnotetext{
${ }^{24}$ lihat Zakiyatul Fakhiroh, Amar Maruf nahi munkar: analisis semiotik dalam film serigala terakhir, komunika, vol. 5. No. 1, Juni 2011, $125-126$
} 
Jangan bicara jangan berisek sek sek

Gek ayo ndang mangkat ndukun, rasah kakean ngelamun

Ndukun, ndukun, ndukun ayo ndukun

And slow, woles woles baby baby

Rasakno aku wes wani perih baby

Rungokno, ku alami hal sama dengan dirimu

Bojoku mencampakkan diriku, podo bojomu podo tanggamu

Dan dudidam aku padamu, I love you

I can't stop loving you oh darling

Jaran goyang menunggumu

Apa salah dan dosaku, sayang, cinta suciku kau buang-buang

Lihat jurus yang kan ku berikan, jaran goyang, jaran goyang

Sayang, janganlah kau waton serem, hubungan kita semula adem

Tapi sekarang kecut bagaikan asem, semar mesem, semar mesem

Ini terakhir, cara tuk dapatkan kamu

Jika ini gagal, kan ku racuni dirimu

Apa salah dan dosaku, sayang, cinta suciku kau buang-buang Lihat jurus yang kan ku berikan, jaran goyang, jaran goyang Sayang, janganlah kau waton serem, hubungan kita semula adem

Tapi sekarang kecut bagaikan asem, semar mesem, semar mesem

Apa salah dan dosaku, sayang, cinta suciku kau buang-buang

Lihat jurus yang kan ku berikan, jaran goyang, jaran goyang

Sayang, janganlah kau waton serem, hubungan kita semula adem

Tapi sekarang kecut bagaikan asem, semar mesem, semar mesem

\section{Pesan dalam Lirik Lagu Jaran Goyang}

Adapun pesan-pesan yang tersirat dalam lirik lagu Jaran Goyang ciptaan Andi Mbendol yang dipopulerkan oleh Nella Kharisma, antara lain:

Pada bait pertama:

Apa salah dan dosaku, sayang

Cinta suciku kau buang-buang

Lihat jurus yang kan ku berikan

Jaran goyang, jaran goyang

Dalam bait tersebut, pengarang meminta kepada sang kekasih untuk menjelaskan apa salah dan dosanya. Mengapa kekasihnya tega mengkhianati cinta suci yang telah terbina selama ini sehingga untuk meluapkan kekesalannya ia mengancam akan memberikan jurus jaran goyang (ilmu ajian pemikat).

Imam Muslim meriwayatkan dalam Shahih-nya bahwa Nabi shallallahu 'alaihi wa sallam bersabda,

"Barangsiapa mendatangi peramal lalu menanyakan kepadanya tentang sesuatu, maka tidak diterima shalatnya selama 40 hari."

Dari Abu Hurairah radhiyallahu 'anhu dari Nabi shallallahu 'alaihi wa sallam, beliau bersabda,

"Barangsiapa mendatangi dukun lalu mempercayai apa yang diucapkannya, maka ia telah kafir terhadap apa yang diturunkan kepada Muhammad." (HR. Abu Daud) 
Hadis ini diriwayatkan juga oleh Ahlus Sunan yang empat dan dishahihkan al-hakim dari Nabi shallallahu 'alaihi wa sallam, dengan redaksi:

"Barangsiapa mendatangi peramal atau dukun lalu mempercayai apa yang dikatakannya, maka ia telah kafir kepada apa yang diturunkan kepada Muhammad."

Dari Imran bin Hushain radhiyallahu 'anhu, ia mengatakan bahwa Rasulullah shallallahu 'alaihi wa sallam bersabda,

"Bukan termasuk golongan kami orang yang mengaitkan kesialannya pada burung (atau benda lainnya), melakukan perdukunan atau meminta didukuni, menyihir atau minta disihirkan untuknya. Dan barangsiapa datang kepada dukun lalu mempercayai apa yang dikatakannya, maka ia telah kafir kepada apa yang diturunkan kepada Muhammad." (HR. al-Bazzar dengan sanad yang baik).

Dalam hadis-hadis tersebut berisi larangan mendatangi para peramal, dukun, penyihir, dan sejenisnya, bertanya dan mempercayai mereka, serta ancaman terhadap hal itu. Kewajiban atas para penguasa, penegak hukum, dan selainnya dari kalangan yang memiliki kemampuan dan kekuasaan, melarang orang-orang mendatangi dukun, peramal dan sejenisnya, melarang menjajakan sesuatu pernik-pernik perdukunan di pasar-pasar/media dan selainnya, melarang mereka dengan tegas, melarang siapa saja yang datang kepada mereka.25

Pada bait kedua:

Sayang, janganlah kau waton serem

Hubungan kita semula adem

Tapi sekarang kecut bagaikan asem

Semar mesem, semar mesem

Pada bait tersebut, pengarang masih menggunakan kata sayang sebagai sapaan terhadap kekasihnya yang kini berlaku seram kepadanya padahal selama ini hubungannya baik-baik saja tanpa adanya gangguan apa pun. Akan tetapi, kini hubungannya menjadi hambar, asam, atau tidak enak lagi seperti semar mesem. Semar mesem merupakan salah satu ilmu pelet yang tenar sejak zaman leluhur, kehebatan mantra semar mesem memang sudat terbukti dan terpercaya mampu menaklukan hati pria maupun wanita dari incaran si pemilik. Hanya dengan sekali kerlingan, tatapan mata si empunya keris semar mesem asli atau ilmu pengasihan ki semar akan memberikan reaksi cepat meluluhkan cinta seseorang sehingga lupa diri, yang tadinya tida suka menjadi sayang, awalnya sulit didapatkan menjadi tergila-gila.

Dalam bahasa arab yang sesuai dengan pengertian pelet yang kita kenal adalah, "At Tiwalah" tiwalah sebagaimana di definisikan oleh syaikh Muhammad bin "Abdul Wahhab adalah sesuatu yang dibuat dengan anggapan bahwasannya hal itu dapat menimbulkan kecintaan istri kepada suaminnya atau suami kepada istrinya. 26

Pelet itu termasuk pebuatan sihir, sedangkan sihir hukumnya haram temasuk perbuatan kekufuran yang menyebabkan pelakunya keluar dari islam (murtad), berkata Syaikh Muhammad Bin 'Abdul Wahhab, pada kitabnya pembatal keislaman : "Pembatal keislaman yang ketujuh SIHIR dan diantara jenis sihir adalah as-sharf dan al-athaf, barangsiapa yang melakukannya atau ridho dengannya maka kafir, dalilnya adalah Firman Alloh Ta'ala :

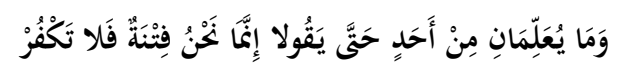

\footnotetext{
${ }^{25}$ https://konsultasisyariah.com/15614-hukum-sihir-dan-perdukunan.html, diakses pada 12 Juli 2019, pukul 12.50

${ }^{26}$ Kitab Tauhid, Syaikh Muhammad Bin Abdul Wahhab hal 77
} 
Artinya : "Dan tidaklah kami megajarkan (sihir) kepada seorang pun sampai kami berkata sesungguhnya kami adalah fitnah (ujian), maka janganlah kalian kafir" (QS. AlBaqarah : 102 )

Pada bait ketiga:

Jurus yang sangat ampuh, teruji terpercaya

tanpa anjuran dokter, tanpa harus muter-muter

cukup siji solusinya, pergi ke mbah dukun saja

Langsung sambat, "Mbah, saya putus cinta"

Pada bagian ini pengarang sudah mulai panas dengan perlakuan kekasihnya, ia benar-benar terkesan marah dan ingin membuat sebuah perhitungan dengan menunjukkan keperkasaannya melalui dukun yang sakti mandraguna. Ia mendatangi dukun tersebut karena percaya dengan jurus ampuh yang pertama ini dan akan dipraktikannya.

Dalam sebuah hadits yang diriwayatkan dari ibnu mas'ud radhiyallahu 'anhu, berkata : "Saya mendengar Rasulullah shalallahu alaihi wassallam bersabda: "Bahwasanya ruqyah (Ruqyah syirkiyah) jimat dan pelet adalah perbuatan syirik"

(HR. Abu Dawud, Imam Ahmad dan selain dari mereka. Dishohihkan Syaikh Al-Albani dalam Silsilah Hadits Shohihah dan dihasankan oleh Syaikh Muqbil bin Hady Al-Wadi'iy dalamShohihul Musnad)

Berkata Syaikh Sholih Fauzan: "Bahwasanya dalam hadits ini terdapat penjelasan bahwa perkara-perkara yang disebutkan dalam hadits ini adalah perbuatan syirik yang dapat menghilangkan Tauhid" ${ }^{27}$

Bekata Syaikh Ahmad An - Najmi, setelah menjelasakan pengertian (at-tilawah : pelet) "Bahkan jika seseorang melakukan demikian itu (pelet) bahwasannya dia telah melakukan macam dari macam sihir, dan sihir perbuatan haram, tidak dapat melakukannya kecuali oarng kafir (karena sihir tidak didapat kecuali dengan kekufuran)"28

Pada bait keempat:

Kalau tidak berhasil, pakai jurus yang kedua

Semar mesem namanya, jaran goyang jodohnya

Cen rodok ndagel syarate, penting di lakoni wae

Ndang di cubo, mesthi kasil terbukti kasiate, genjrot

Jika jurus yang pertama tidak berhasil, ia masih memiliki jurus yang kedua untuk menaklukkan kekasih hatinya meskipun syaratnya sedikit lucu dan menggelitik. Tetapi akan tetap dicoba dan dilakukan, sebab pasti akan terbukti khasiatnya atau efek yang akan diterima oleh objek yang dituju.

Terjalinya kerja sama antara jin dan dukun tentu memiliki kensekwensi dan komitmen yang mesti dipenuhi oleh kedua belah pihak. Di antara bentuk komitmen dan kensekwensi tersebut, sang dukun harus menuruti persyaratan yang diminta oleh Jin. Setelah hal itu dilakukan sang dukun maka kemudian jin membantu sang duku dalam praktek profesinya sebagai dukun. Biasanya persyaratan itu tidak rumit, cukup melakukan salah satu bentuk kesyirikan atau kekufuran saja, meskipun sang dukun tetap melakukan amalan ibadah yang zhahir seperti shalat, puasa dan lain sebagainya.

\footnotetext{
${ }^{27}$ Mulakhos Syarah Kitab Tauhid, hal. 79

${ }^{28}$ Syarh kitab tauhid Syaikh Ahmad An Najmi:73
} 
Dan kadang kala yang menjadi persyaratan itu melakukan ibadah yang menyelisihi Sunnah Rasûlullâh Shallallahu 'alaihi wa sallam. Sehingga dengan demikian, tanpa disadari sang dukun terjebak dalam sebuah dosa yang selalu dilakukan dalam hidupnya. Dia tidak menyadari itu sebagai sebuah dosa dan kesalahan. Yang lebih populer dalam istilah ulama, yaitu amalan-amalan bid'ah.

Ketika telah terjalin kerjasama yang erat, maka jin berupaya membantu sang dukun dalam mengetahui berita-berita ghaib. Bagaimana cara jin mendapatkan berita-berita ghaib tersebut? Jawabannya terdapat pada hadits berikut ini:

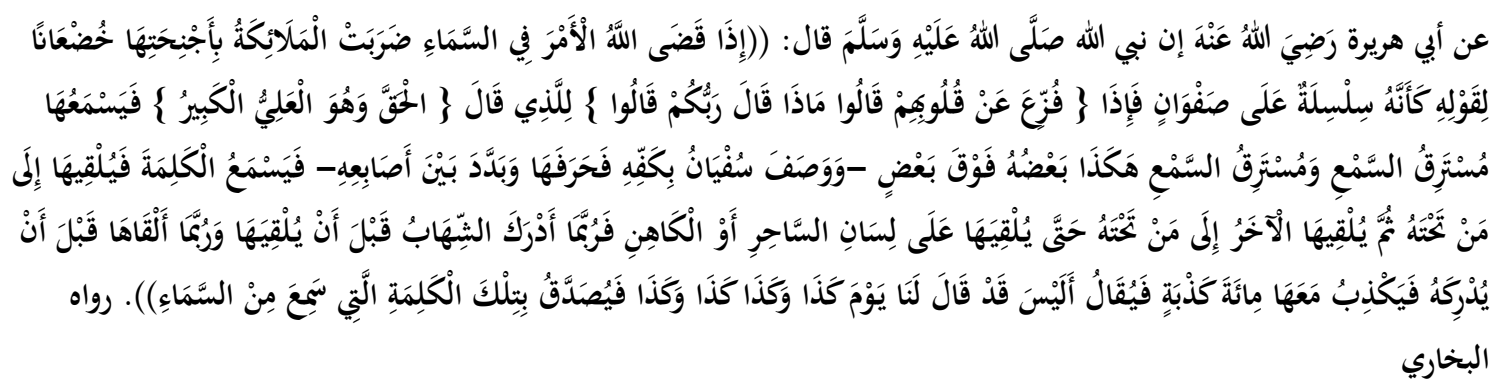

Artinya: Dari Abu Hurairah Radhiyallahu anhu, bahwa Nabi Shallallahu 'alaihi wa sallam bersabda: "Apabila Allâh memutuskan sebuah perintah di langit, para malaikat menundukkan sayap-sayap mereka dengan penuh takut, bagaikan suara rantai yang ditarik di atas batu putih. Apabila telah hilang rasa takut dari hati mereka, mereka bertanya: 'Apa yang dikatakakan oleh Tuhan kalian?' Jibril menjawab: 'Tentang kebenaran dan Ia Maha Tinggi lagi Maha Besar'. Lalu para pencuri berita langit (setan) mendengarnya. Mereka para pencuri berita langit tersebut seperti ini, sebahagian mereka di atas sebagian yang lain -Sufyan (rawi hadits) mencontohkan dengan jari-jarinya- maka yang paling di atas mendengar sebuah kalimat lalu membisikannya kepada yang di bawahnya, kemudian selanjutnya ia membisikan lagi kepada yang di bawahnya dan begitu seterusnya sampai ia membisikannya kepada tukang sihir atau dukun. Kadang-kadang ia disambar oleh bintang berapi sebelum menyampaikannya atau ia telah menyampaikannya sebelum ia disambar oleh bintang berapi. Maka setan mencampur berita tersebut dengan seratus kebohongan. Maka dikatakan orang: bukan ia telah berkata kepada kita pada hari ini dan ini... maka ia dipercaya karena satu kalimat yang pernah ia dengan langit tersebut' ${ }^{29}$

Dalam hadits di atas ada berapa point yang dapat kita jelaskan.

Pertama, dalam hadits tersebut diterangkan bagaimana proses jin dalam mencari berita-berita ghaib. Yaitu dengan bertengger satu di atas yang lainnya seperti pertunjukkan orang memanjat pinang atau seperti seni olah raga yang dilakukan di sekolah-sekolah. Yaitu dengan cara lima orang di bawah, lalu pada tingkat kedua naik empat orang, kemudian pada tingkat berikut tiga orang, dan begitu seterusnya.

Kedua, berita ghaib yang mereka dapatkan itu berasal dari perkataan Allâh Subhanahu wa Ta'ala kepada para malaikat untuk melakukan tugas tertentu, lalu para malaikat saling berkomunikasi antara satu dengan yang lainnya. Melalui percakapan malaikat tersebut, jin mencuri dengar dan menyampaikannya kepada mitranya dari kalangan dukun.

Ketiga, bahwa para jin tidak senantiasa dapat mencuri berita langit tersebut karena Allâh Subhanahu wa Ta'ala menjadikan sebagian bintang untuk melempar mereka yang berusaha mencuri dengar berita langit tersebut.

\footnotetext{
${ }^{29}$ HR al-Bukhâri, 4/1804 (4522)
} 
Keempat, jika jin selamat dari lemparan bintang yang berapi, barulah mereka berhasil mencuri satu kalimat dari berita langit. Artinya, jin tidak mengetahui secara detail atau seutuhnya tentang berita langit tersebut. Lalu berita tersebut mereka campur dengan seratus kedustaan.

Kelima, bahwa sebab adanya manusia yang mempercayai dukun adalah gara-gara tidak melihat kebohongan jin dan hanya mengingat satu kalimat yang terdapat seratus kebohongan. Lalu kalimat yang satu tersebut diekspos kemana-mana, namun tidak mengekspos kebohongannya yang begitu banyak. ${ }^{30}$

Pada bait kelima:

Dan dudidam aku padamu

I love you, I can't stop loving you oh darling

Jaran goyang menunggumu

Karena dirinya sangat mencintai kekasihnya. Maka ia benar-benar serius akan memakai jarang goyang sebagai ajian yang ampuh, ia terus mengancam bahwasannya jaran goyang semakin dekat.

Pada bait keenam:

Wes cukup stop mandekko disek sek sek

Jangan bicara jangan berisek sek sek

Gek ayo ndang mangkat ndukun, rasah kakean ngelamun

Ndukun, ndukun, ndukun ayo ndukun

And slow, woles woles baby baby

Rasakno aku wes wani perih baby

Rungokno, ku alami hal sama dengan dirimu

Bojoku mencampakkan diriku, podo bojomu podo tanggamu

Pada bait ini sangat riskan sekali dengan tekadnya yang kuat untuk mengajak pergi ke dukun dengan segera tanpa banyak berpikir apalagi pertimbangan yang cukup matang, ia benar-benar tidak ingin mendengar celotehan apapun, intinya bisa membalaskan dendamnya kepada orang yang telah menyakitinya sehingga akan cepat terselesaikan juga permasalahannya. Ia sudah cukup merasa sakit karena telah di putuskan cinta oleh kekasih. Dengan demikian diharapkan jika memang sudah bosan atau sudah tidak memiliki ketertarikan terhadap pasangan maka lebih baik jujur apa adanya daripada nantinya akan menimbulkan hal-hal yang negatif terjadi. Jujur adalah satu kata yang memiliki banyak makna, dan ketika hal tersebut diutarakan maka bersiap-siaplah untuk menerima kenyataan berupa kepahitan atau bahkan kebahagiaan yang tiada tara.

Ibnu Mas'ud radhiyallahu 'anhu berkata bahwa beliau mendengar Rasulullah shallallahu 'alaihi wa sallam bersabda,

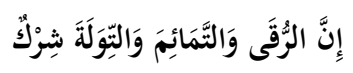

Artinya: "Sesungguhnya mantera-mantera, jimat-jimat dan pelet adalah syirik",31.

Tiwalah yang dimaksud dalam hadits ini adalah sesuatu yang dibuat dan diklaim bisa membuat perempuan lengket pada suami dan sebaliknya. ${ }^{32}$ Jadi bisa saja tiwalah itu berupa pelet, jimat, susuk, dan bulu perindu. Namun sebagian ulama mengatakan bahwa tiwalah yang dimaksud adalah jika berasal dari sihir. ${ }^{33}$. Al Hafizh Ibnu Hajar mengatakan bahwa tiwalah ini diperoleh dari jalan sihir $^{34 .}$ Sehingga jika pemikat hati atau pemikat cinta berupa susuk, jimat dan

\footnotetext{
${ }^{30}$ https://almanhaj.or.id/4304-ilmu-perdukunan-dalam-tinjauan-islam.html, diakses tanggal 11 Juli 2019, pukul 11.50

${ }^{31}$ HR. Abu Daud no. 3883, Ibnu Majah no. 3530 dan Ahmad 1: 381. Syaikh Al Albani mengatakan bahwa hadits ini shahih

${ }^{32}$ Kitab Tauhid, Syaikh Muhammad At Tamimi

${ }^{33}$ Syarh Kitab Tauhid, hal. 62

${ }^{34}$ Fathul Bari, 10: 196
} 
bulu perindu, maka termasuk dalam kategori tamimah (jimat-jimat). Dan jimat-jimat itu terlarang sebagaimana telah disebutkan pula dalam hadits di atas.

Memakai pelet termasuk syirik karena di dalamnya ada keyakinan untuk menolak bahaya dan mendatangkan manfaat dari selain Allah Ta'ala ${ }^{35}$. Syaikh Muhammad bin Sholeh Al 'Utsaimin berkata, "Tiwalah tergolong syirik karena tiwalah bukanlah sebab syar'i (yang didukung dalil) dan bukan pula sebab qodari (yang dibuktikan melalui eksperimen)."36

\section{Kesimpulan}

Temuan penelitian ini menunjukkan bahwasanya:

Berdasarkan penelitian metode kualitatif dengan pendekatan etnografi virtual yang dilakukan maka Lirik lagu dalam lagu Jaran Goyang menunjukkan ajakan atau informasi yang tidak baik dalam ajaran agama Islam. Bahkan lirik nya Bertentangan dengan Konsep Amar Mar'uf nahi mungkar.

Ajakan menggunakan dukun untuk memelet sang pacar, sangat bertentangan dengan ajaran Islam, namun lagu jaran goyang dapat dikatakan sangat fenomenal dengan viewer di Youtube mencapai 235 juta untuk video live nya dan 53 Juta penonton untuk official videonya.

Nada yang mudah didengar dan mudah ditiru sebenarnya menjadi kesempatan baik bagi para pendakwah untuk melaksanakan kegiatan amar ma'ruf nahi mungkar menggunakan sarana lagu tersebut, namun dengan mengganti liriknya menjadi lirik shalawat ataupun ajakan untuk beribadah

\section{DAFTAR PUSTAKA}

Afriyanti, N. 2017. Teks Tembang Lir-ilir Pada Pernikahan Adat Jawa (Kajian Semiotik) (Doctoral dissertation, UNIMED).

Al Qoulul Mufid, Syaikh Muhammad bin Sholeh Al 'Utsaimin, terbitan Dar Ibnul Jauzi, cetakan kedua, tahun $1424 \mathrm{H}$.

Andrew N. Weintraub, 2010, A social and Musical History Indonesia's Most Popular Music (Oxford University.

Anselm Straus \& Juliet Corbin, 2013. Dasar-dasar Penelitian Kualitatif, (Yogyakarta: Pustaka Pelajar

Ardiyanti, D., \& Setyorini, R. 2018. Analisis Campur Kode pada Lirik Lagu Jaran Goyang Dipopulerkan oleh Nella Kharisma. SAP (Susunan Artikel Pendidikan),

Ariani, Iva, 2011. Ajaran Tasawuf Sunan Kalijaga dan Pengaruhnya bagi Perkembangan Pertunjukan Wayang Kulit di Indonesia. Fakultas Filsafat UGM, Yogyakarta

Arifani, M. A. 2010. Model pengembangan dakwah berbasis budaya lokal. Ilmu Dakwah: Academic Journal for Homiletic Studies,

Devi Ardiyanti dan Ririn Setyorini, Analisis campur kode pada lirik lagu jaran goyang dipopulerkan oleh Nella Kharisma, jurnal SAP vol. 2 No. 3 April 2018

Donny Khoirul Azis, Akulturasi Islam dan Budaya Jawa. Fikrah, Fikrah, Vol. I, No. 2, JuliDesember 2013,

\footnotetext{
${ }^{35}$ Fathul Majid, 139

${ }^{36}$ https://rumaysho.com/2397-kesyirikan-pada-pelet-dan-susuk-pemikat-hati.html, diakses tanggal 11 Juli 2019, jam 10.53
} 
Fathul Majid, Syaikh 'Abdurrahman bin Hasan Alu Syaikh, terbitan Darul Ifta', cetakan ketujuh, $1431 \mathrm{H}$.

Hine, C. 2000. Virtual Ethnography. London: Sage Publications Ltd.

HR al-Bukhâri, 4/1804 (4522)

HR. Abu Daud no. 3883, Ibnu Majah no. 3530 dan Ahmad 1: 381.

Kamaluddin, M. 2018. Representasi Multikultural dalam Pertunjukkan Musik Dangdut Koplo. Proceeding of The URECOL,

Mariampolski. H. "The Power of Etnography," International Journal of Market Research, 41 (1), Mulakhos Syarah Kitab Tauhid

Mustolehudin, M. 2012. Nilai-nilai Moral dalam Lirik Musik Dangdut Rhoma Irama antara Tahun 1970-1980 (Doctoral dissertation, IAIN Walisongo)

.Pandu Diptya Yoga, 2013. Hubungan Antara Musik Dangdut Koplo dan Lingkungan gang Doly, Apron: Jurnal Pemikiran Seni Pertunjukan, Unesa, Vol.2 No. 2.

Raditya, M. H. 2013. Dangdut Koplo: Selera Lokal Menjadi Selera Nasional. Jurnal Seni Musik.

Raditya, M. H., \& Simatupang, G. L. L. 2018. Negosiasi Kultural dan Musikal Dangdut Koplo pada Orkes Melayu Sonata di Jombang. Panggung,

Rulli Nasrullah, 2014, Teori Dan Riset Media Siber, Jakarta: Prenada Media Group

Syarh kitab tauhid Syaikh Ahmad An Najmi

Syarh Kitab Tauhid, Syaikh Hamd bin 'Abdillah Al Hamd, terbitan Maktabah Ar Rusyd, cetakan kedua, $1431 \mathrm{H}$.

Zakiyatul Fakhiroh, Amar Maruf nahi munkar: analisis semiotik dalam film serigala terakhir, komunika, vol. 5. No. 1, Juni 2011, 125-126

Zuhdi, M. H, 2017. Dakwah dan Dialektika Akulturasi Budaya. RELIGIA.

\section{Referensi Website:}

http://suryamalang.tribunnews.com/2017/12/29/inilah-top-song-di-asean-lagu-jaran-goyangmilik-nella-kharisma-berada-di-urutan-nomor?page $=4$.

https://almanhaj.or.id/4304-ilmu-perdukunan-dalam-tinjauan-islam.html, diakses tanggal 11 Juli 2019, pukul 11.50

https://konsultasisyariah.com/15614-hukum-sihir-dan-perdukunan.html, diakses pada $12 \mathrm{Juli}$ 2019, pukul 12.50

https://news.detik.com/jawatimur/4326740/tawuran-antar-pemuda-terjadi-usai-nonton-konserdangdut, diakses 18 Februari 2019. Berita terkait tawuran pasca atau saat pertunjukan dangdut terkadang disebabkan persoalan kecil yang dibesar-besarkan oleh geng atau pemuda yang mabuk. Lihat juga tawuran antar penonton orkes New Pallapa Jombang tahun 2018 dalam tayangan media audio visual Youtube https://www.youtube.com/watch?v=bOHh2uvDQNQ

https://rumaysho.com/2397-kesyirikan-pada-pelet-dan-susuk-pemikat-hati.html, diakses tanggal 11 Juli 2019, jam 10.53 
https://www.kompasiana.com/ginanjarinu/5528a6116ea834025e8b45cb/musik-dan-penyebaranagama-islam

http://e-journal.iainpekalongan.ac.id/index.php/Religia/article/view/122 Date accessed: 19 feb. 2019. 